Review

\title{
Fluorine-18 labeled amino acids for tumor PET/CT imaging
}

\author{
Yiqiang Qi $i^{1,2, *}$, Xiaohui Liu ${ }^{1,2, *}$, Jun $\mathrm{Li}^{4}$, Huiqian $\mathrm{Yao}^{5}$ and Shuanghu Yuan ${ }^{2,3}$ \\ ${ }^{1}$ School of Medicine and Life Sciences, University of Jinan-Shandong Academy of Medical Sciences, Jinan, Shandong, China \\ ${ }^{2}$ Department of Radiation Oncology, Shandong Cancer Hospital and Institute, Shandong Cancer Hospital affiliated to \\ Shandong University, Jinan, Shandong, China \\ ${ }^{3}$ Shandong Academy of Medical Sciences, Jinan, Shandong, China \\ ${ }^{4}$ Department of Thoracic Surgery, Shandong Provincial Hospital, Jinan, Shandong, China \\ ${ }^{5}$ Department of Surgery, Juye Coalfield Central Hospital, Heze, Shandong, China \\ *Authors contributed equally to this work
}

Correspondence to: Shuanghu Yuan, email: yuanshuanghu@sina.com

Keywords: Fluorine-18 labeled amino acids, positron emission tomography/computed tomography (PET/CT), tumor metabolism, molecular imaging

Received: May 25, 2017 Accepted: July 25, $2017 \quad$ Published: August 04, 2017

Copyright: Qi et al. This is an open-access article distributed under the terms of the Creative Commons Attribution License 3.0 (CC BY 3.0), which permits unrestricted use, distribution, and reproduction in any medium, provided the original author and source are credited.

\section{ABSTRACT}

Tumor glucose metabolism and amino acid metabolism are usually enhanced, ${ }^{18}$ F-FDG for tumor glucose metabolism PET imaging has been clinically well known, but tumor amino acid metabolism PET imaging is not clinically familiar. Radiolabeled amino acids (AAs) are an important class of PET/CT tracers that target the upregulated amino acid transporters to show elevated amino acid metabolism in tumor cells. Radiolabeled amino acids were observed to have high uptake in tumor cells but low in normal tissues and inflammatory tissues. The radionuclides used in labeling amino acids include ${ }^{15} \mathrm{O},{ }^{13} \mathrm{~N},{ }^{11} \mathrm{C},{ }^{123} \mathrm{I},{ }^{18} \mathrm{~F}$ and ${ }^{68} \mathrm{Ga}$, among which the most commonly used is ${ }^{18} \mathrm{~F}$ [1]. Available data support the use of certain ${ }^{18} \mathrm{~F}$-labeled AAs for PET/CT imaging of gliomas, neuroendocrine tumors, prostate cancer and breast cancer $[2,3]$. With the progress of the method of ${ }^{18} \mathrm{~F}$ labeling AAs [4-6], ${ }^{18} \mathrm{~F}$-labeled AAs are well established for tumor PET/CT imaging. This review focuses on the current status of key clinical applications of 18F-labeled AAs in tumor PET/CT imaging.

\section{INTRODUCTION}

The clinical applications of tumor PET imaging are very extensive, including diagnosis, confirming status of lymph node and distant metastasis, and evaluating of curative effect. ${ }^{18} \mathrm{~F}$-labeled AAs have been used for tumor PET imaging for decades, these are an important class of PET imaging agents that target the increased levels of AA transport by many types of tumor cells. System L AA transporter has been a major focus of imaging agents development, and work in this field has led to several ${ }^{18} \mathrm{~F}$-labeled AAs as PET tracers, such as ${ }^{18} \mathrm{~F}$-FET, ${ }^{18} \mathrm{~F}$-FDOPA, ${ }^{18} \mathrm{~F}-\mathrm{D}-\mathrm{FMT},{ }^{18} \mathrm{~F}-\mathrm{FAMT},{ }^{18} \mathrm{~F}-\mathrm{OMFD}$, and ${ }^{18} \mathrm{~F}$-FACBC. Recently, emerging ${ }^{18} \mathrm{~F}$-labeled AAs have been developed that target system A, xCT, glutamine, and cationic amino acid transporters [7]. So far, the main clinical applications of ${ }^{18} \mathrm{~F}$-labeled AAs are gliomas, neuroendocrine tumors, prostate cancer and breast cancer PET/CT imaging.
Mechanism of amino acid metabolism for tumor PET imaging

Certain AA transporters, particularly LAT1 and ASCT2 [8-10], are upregulated in a wide range of different types of tumors, there is growing evidence that some AA transporters and their substrates interact with the mammalian target of rapamycin (mTOR) pathway, which regulates cell proliferation and protein synthesis $[11,12]$. These upregulated AA transporters increase much more amino acid uptake of tumors. ${ }^{18} \mathrm{~F}$-labeled amino acids are an important class of tumor imaging agents suitable for PET/CT. PET is a kind of radiotracer-based imaging method, which can provide unique, noninvasive molecular and functional information about tumor biology that complements more anatomically based modalities, such as magnetic resonance imaging (MRI) and computed tomography $(\mathrm{CT}) .{ }^{18} \mathrm{~F}$-labeled AAs detect increased tumor 
amino acid metabolism levels by targeting upregulated AA transporters in PET imaging, the key of that is the amino acid transport system $[1,2,13,14]$. Amino acids enter cells through membrane-associated transporter, and more than 20 amino acid transporters have been discovered in mammalian cells [15-18]. According to the need for sodium ions, amino acid transport system can be divided into the following two categories [10, 19-21]: (1) $\mathrm{Na}^{+}$-dependent amino acid transport systems, including system ASC (alanine-serine-cysteine preferred), system A (alanine preferred), system N (glutamine, aspartic acid and histidine preferred), X- AG(transport L-glutamic acid, D-/L-aspartic acid) and $\mathrm{B}^{0+}$ (transport neutral and basic amino acids); (2) $\mathrm{Na}^{+}$-undependent amino acid transport systems, including system L (leucine preferred), $\mathrm{y}^{+}$(CAT) (selectively transport basic amino acids), $\mathrm{y}^{+} \mathrm{L}$ (transport neutral and basic amino acids), $\mathrm{b}^{0+}$ (transport neutral and basic amino acids) and $\mathrm{X}-\mathrm{C}$ (transport cystine and glutamic acid). The system A, system L and system ASC are the most common amino acid transport systems [16, 22-26].

\section{PET tracers based on ${ }^{18} \mathrm{~F}$-labeled amino acids}

${ }^{18} \mathrm{~F}$-labeled amino acids are an class of the most commonly used tracers for tumor PET imaging, the ideal PET tracers based on ${ }^{18} \mathrm{~F}$-labeled AAs should conform to the following conditions: (1) can be quickly transported to the tumor cells, and have a high uptake rate and a certain retention time; (2) do not combine with non-protein and inflammatory tissue; (3) have a high plasma clearance rate; (4) have a better blood-brain barrier permeability for the brain tumors; (5) have a relatively simple and practical labeling method [18, 27]. At present, clinical commonly used ${ }^{18} \mathrm{~F}$-labeled amino acids are basically in line with the above conditions, these are listed in Table 1.

\section{Clinical applications of ${ }^{18} \mathrm{~F}$-labeled amino acids in tumor PET/CT imaging}

\section{Gliomas}

Gliomas are occurring in the neuroectodermal, are also known as neuroectodermal tumors or neuroepithelial tumors. Contrast-enhanced MRI plays a critical role in glioma imaging, including diagnosis, monitoring response to therapy, staging, and assessing for recurrence, but has limited accuracy for distinguishing between recurrence and radiation necrosis, and evaluating the nonenhancing portions of gliomas. The value of ${ }^{18} \mathrm{~F}$-labeled AAs PET in delineating metabolic tumor volume, evaluating the tumor metabolic load and as a reference for treatment response is better than MRI. The metabolic information of ${ }^{18} \mathrm{~F}-\mathrm{FDG}$ PET/CT has improved the diagnostic evaluation of a number of human malignancies [28-31]. However, ${ }^{18} \mathrm{~F}-\mathrm{FDG}$ is limited by high uptake in normal brain, that interfere with the identification of glioma and normal brain. Two major advantages of ${ }^{18} \mathrm{~F}$-labeled AAs for glioma imaging are their relatively low uptake and retention in normal brain and ability to visualize the entire glioma volume, compared with ${ }^{18} \mathrm{~F}-\mathrm{FDG}$ PET/CT $[7,27,32] .{ }^{18} \mathrm{~F}$-labeled AAs that useful for glioma PET/ $\mathrm{CT}$ imaging include ${ }^{18} \mathrm{~F}$-FDOPA, ${ }^{18} \mathrm{~F}-\mathrm{OMFD},{ }^{18} \mathrm{~F}-\mathrm{FET}$, ${ }^{18} \mathrm{~F}$-FAMT, 2-FTyr, ${ }^{18} \mathrm{~F}$-BPA, ${ }^{18} \mathrm{~F}$-FSPG and ${ }^{18} \mathrm{~F}$-FGln, the most commonly used are ${ }^{18} \mathrm{~F}$-FDOPA and ${ }^{18} \mathrm{~F}$-FET. Both visual and semiquantitative indices of ${ }^{18} \mathrm{~F}$-FDOPA PET detected glioblastoma recurrence with high accuracy and were predictive for PFS (progression-free survival) [33]. There was a study suggests that ${ }^{18} \mathrm{~F}$-FET PET/CT adds valuable diagnostic information in brainstem and spinal cord glioma, particularly when the diagnostic information derived from MRI is equivocal [34]. A systematic review and meta-analysis indicates that ${ }^{18} \mathrm{~F}$-FET PET/ CT demonstrated excellent performance for diagnosing primary brain tumors [35]. ${ }^{18} \mathrm{~F}-\mathrm{FET}$ may also be used for distinguishing recurrent brain metastasis from radiation necrosis after radiation therapy [36], but additional data are needed in this field. ${ }^{18} \mathrm{~F}$-FDOPA uptake on PET was associated with IDH (isocitrate dehydrogenase) mutation in newly diagnosed gliomas [37]. ${ }^{18} \mathrm{~F}-\mathrm{FDOPA}$ PET/CT and fused ${ }^{18} \mathrm{~F}-\mathrm{FDOPA}$ PET/MRI are also used for detecting striatal involvement in children with gliomas [38]. ${ }^{18} \mathrm{~F}-\mathrm{BPA}$ (boron phenylalanine) is used for the tumor/ normal tissue ratio in boron neutron capture therapy of gliomas and other head and neck cancers [39-41]. ${ }^{18}$ F-FSPG was a novel PET radiopharmaceutical which demonstrated high uptake in intracranial malignancies studies of both small animal and human [42]. ${ }^{18}$ F-FGln showed high uptake in gliomas but low background brain uptake, facilitating clear tumor delineation [43-46].

\section{Neuroendocrine tumors}

Neuroendocrine tumors (NETs) are a class of heterogeneous tumors that originate from peptidergic neurons and neuroendocrine cells, arise in different anatomic locations and are associated with symptoms resulting from the hormones or vasoactive peptides. Neuroendocrine tumors include carcinoid tumors, pheochromocytomas and paragangliomas, pancreatic islet cell tumors, medullary thyroid cancer, neuroblastoma, and small cell lung cancer [7, 47]. These tumors have been known as tumors with amine precursor uptake and decarboxylation (APUD) $[48,49]$. APUD tumor cells can uptake and decarboxylate amine precursor such as 5-hydroxy-L-tryptophan (5HTP) and L-dihydroxyphenylalanine (L-DOPA) and pass through aromatic L-amino acid decarboxylase (AADC) to decarboxylate them to the corresponding 5-hydroxy-L-tryptamine and dopamine. ${ }^{18} \mathrm{~F}$-FDOPA has proved a valuable tool for the assessment of neuroendocrine tumors. ${ }^{18} \mathrm{~F}-\mathrm{FDOPA} \mathrm{PET} / \mathrm{CT}$ is highly 
Table 1: Clinical applications of ${ }^{18} \mathrm{~F}$-labeled amino acids

\begin{tabular}{|c|c|c|c|}
\hline Abbreviation & Full name of tracers & Transport system & Clinical applications \\
\hline${ }^{18} \mathrm{~F}-\mathrm{FDOPA}$ & $\begin{array}{l}\text { L-3,4-dihydroxy- } 6-{ }^{18} \text { F-fluoro- } \\
\text { phenylalanine }\end{array}$ & $\begin{array}{l}\text { System L and Amino } \\
\text { acid decarboxylase }\end{array}$ & $\begin{array}{l}\text { Brain tumors and Neuroendocrine } \\
\text { tumors }\end{array}$ \\
\hline${ }^{18} \mathrm{~F}-\mathrm{OMFD}$ & $\begin{array}{l}\text { 3-O-methyl-6- }{ }^{18} \text { F-fluoro-L-3,4- } \\
\text { dihydroxyphenylalanine }\end{array}$ & System L & Brain tumors \\
\hline${ }^{18} \mathrm{~F}-\mathrm{FET}$ & O- $\left(2-{ }^{18} \mathrm{~F}\right.$-fluoroethyl $)$-L-tyrosine & System L & Brain tumors \\
\hline${ }^{18} \mathrm{~F}-\mathrm{FAMT}$ & $\begin{array}{l}\mathrm{L}-3-{ }^{18} \mathrm{~F} \text {-fluoro-alpha-methyl } \\
\text { tyrosine }\end{array}$ & System L & $\begin{array}{l}\text { Brain tumors, Oral cavity cancer and } \\
\text { Non-small cell lung cancer }\end{array}$ \\
\hline 2-FTyr & $2-{ }^{18} \mathrm{~F}$-fluoro-L-tyrosine & System L & Brain tumors \\
\hline${ }^{18} \mathrm{~F}-\mathrm{FG} \ln$ & $4-{ }^{18} \mathrm{~F}-(2 \mathrm{~S}, 4 \mathrm{R})$-fluoro-glutamine & System L and ASCT2 & Brain tumors and Breast cancer \\
\hline${ }^{18} \mathrm{~F}-\mathrm{D}-\mathrm{FMT}$ & O- ${ }^{18} \mathrm{~F}$-fluoromethyl-D-tyrosine & System L & Non-small cell lung cancer \\
\hline $\begin{array}{l}{ }^{18} \mathrm{~F}-\mathrm{FSPG} \quad(\mathrm{BAY} \\
94-9392)\end{array}$ & $\begin{array}{l}\text { (4S)-4-(3- }{ }^{18} \mathrm{~F} \text {-fluoropropyl)-L- } \\
\text { glutamate }\end{array}$ & System $\mathrm{X}_{\mathrm{C}}^{-}$ & $\begin{array}{l}\text { Brain tumors, Lung cancer and Liver } \\
\text { cancer }\end{array}$ \\
\hline${ }^{18} \mathrm{~F}-\mathrm{FASu}$ & ${ }^{18} \mathrm{~F}$-5-fluoroaminosuberic acid & System $\mathrm{X}_{\mathrm{C}}^{-}$ & Breast cancer \\
\hline${ }^{18} \mathrm{~F}-\mathrm{FACBC}$ & $\begin{array}{l}\text { anti-1-amino- } 3-{ }^{18} \mathrm{~F}- \\
\text { fluorocyclobutane-1-carboxylic acid }\end{array}$ & System L and ASCT2 & Prostate cancer and Breast cancer \\
\hline${ }^{18} \mathrm{~F}-\mathrm{FACPC}$ & $\begin{array}{l}\text { anti-1-amino- } 2-{ }^{18} \mathrm{~F} \text { - } \\
\text { fluorocyclopentane-1-carboxylic } \\
\text { acid }\end{array}$ & System L and ASCT2 & Prostate cancer \\
\hline${ }^{18} \mathrm{~F}$-Cis-FPro & cis-4- ${ }^{18} \mathrm{~F}$-fluoro-L-proline & System $\mathrm{A}$ and $\mathrm{B}^{0,+}$ & Urinary system tumors \\
\hline
\end{tabular}

sensitive in posttreatment evaluation of patients with pheochromocytomas and paragangliomas, and better than MRI and CT [50-52]. ${ }^{18} \mathrm{~F}$-FDOPA is also suited for imaging gastroenteropancreatic neuroendocrine tumors and neuroblastoma [53-56]. ${ }^{18} \mathrm{~F}-\mathrm{FDOPA}$ PET/ $\mathrm{CT}$ detected more positive body regions and lesions of carcinoid tumors than the combination of CT and SRS $[55,57-61] .{ }^{18} \mathrm{~F}-\mathrm{FDOPA}$ may play a potentially useful role in medullary thyroid cancer PET imaging as a better or at least complementary model [55, 62, 63]. However, for pancreatic islet cell tumors, the ${ }^{18} \mathrm{~F}$-FDOPA PET is not significant [55, 64-66].

\section{Prostate cancer}

According to the WHO global tumor epidemiology statistics (GLOBOCAN 2008), prostate cancer in 2008 ranked second in global male malignancy incidence (second only to lung cancer), accounting for $14 \%$ of all men with cancer [67]. CT and MR imaging has limited accuracy to detect the primary tumor and regional lymph node metastases. Typically, prostate cancer has a lower ${ }^{18} \mathrm{~F}-\mathrm{FDG}$ uptake rate. Recent studies with ${ }^{18} \mathrm{~F}-\mathrm{FACBC}$ and ${ }^{18} \mathrm{~F}$-FACPC have shown that these ${ }^{18} \mathrm{~F}$-labeled AA tracers can accurately detect tumor and regional lymph node metastases with better specificity and sensitivity $[7,68,69]$. Because ${ }^{18} \mathrm{~F}$-FACBC is slowly excrete into the bladder, the background radioactivity in the pelvic cavity is low, and the tumor and lymph node metastasis of primary and recurrent prostate cancer can be clearly visualized
[70]. In addition, there were studies show that ${ }^{18} \mathrm{~F}-\mathrm{FACBC}$ was superior in detecting prostate cancer recurrence in patients with recurrent prostate cancer compared with ${ }^{111} \mathrm{In}$-capromab or ${ }^{11} \mathrm{C}$-choline [71-74]. Since the half-life of ${ }^{11} \mathrm{C}$ is only 20.3 minutes, the use of ${ }^{11} \mathrm{C}$-choline PET is limited in institute with on-site cyclotron. Furthermore, in the case of natural amino acids such as $\mathrm{L}-{ }^{11} \mathrm{C}$-methionine (MET), rapid metabolism usually produces radiolabeled metabolites, which can confuse kinetic analysis and reduce image quality $[75,76] .{ }^{18} \mathrm{~F}-\mathrm{FACBC}$ could be considered an alternative tracer superior to ${ }^{11} \mathrm{C}$-choline in the setting of patients with biochemical recurrence after radical prostatectomy $[71,77-80]$. ${ }^{18} \mathrm{~F}$-fluciclovine $\mathrm{PET} / \mathrm{CT}$ is also used for distinguishing between prostate tumours and benign tissue and for assessment of tumour aggressiveness [81]. A study of ${ }^{18} \mathrm{~F}-\mathrm{FACBC}$ PET/CT used in the planning of radiation therapy for prostate cancer patients has also been reported [82].

\section{Breast cancer}

Recent studies [83-85] have shown that ${ }^{18} \mathrm{~F}$-fluciclovine that is a leucine analog radioactive tracer can also be used for breast cancer PET/CT imaging. ${ }^{18} \mathrm{~F}$-fluciclovine $\mathrm{PET} / \mathrm{CT}$ visualizes malignant tumors including invasive lobular breast cancer (ILC) and invasive ductal breast cancer (IDC). In primary and metastatic breast cancers, ${ }^{18} \mathrm{~F}$-fluciclovine uptake was significantly higher than benign breast lesions and normal breast tissue. Changes in ${ }^{18} \mathrm{~F}$-fluciclovine avidity were strongly 
associated with a reduction in the percentage of tumor on pathology caused by treatment [3]. In addition to detecting and locating breast cancer, ${ }^{18} \mathrm{~F}$-fluciclovine may provide a new tool for the exploration of amino acid transport and metabolism in breast cancer. ${ }^{18} \mathrm{~F}$-fluciclovine also detected lymph nodes and bone metastases, but liver metastases were less effective due to the high physiological uptake of the tracer in liver parenchyma. The highest uptake of ${ }^{18} \mathrm{~F}$-fluciclovine appears in Nottingham grade 3 cancers and triple-negative breast cancers, suggesting that ${ }^{18} \mathrm{~F}$-fluciclovine may play a role in identifying more aggressive malignancies [83-85]. ${ }^{18} \mathrm{~F}-\mathrm{FASu}$ may serve as a valuable target for the diagnosis and treatment monitoring of certain breast cancers and may provide more sensitive detection than ${ }^{18} \mathrm{~F}-\mathrm{FDG}$ in certain tumors [86, 87]. ${ }^{18} \mathrm{~F}-\mathrm{FG}$ In PET could be used to track cellular glutamine pool size of triple-negative breast cancers [88].

\section{CONCLUSIONS}

${ }^{18} \mathrm{~F}$-labeled amino acids have been developed for preclinical and clinical tumor PET/CT imaging. ${ }^{18} \mathrm{~F}$-FDOPA and ${ }^{18} \mathrm{~F}$-FET are well established for diagnosis, monitoring response to therapy, staging, and assessing for recurrence of gliomas. ${ }^{18} \mathrm{~F}$-FDOPA has proved a valuable tool for the assessment of neuroendocrine tumors. It is highly sensitive in posttreatment evaluation of patients with pheochromocytomas and paragangliomas, and suited for imaging gastroenteropancreatic neuroendocrine tumors and neuroblastoma. Studies with ${ }^{18} \mathrm{~F}-\mathrm{FACBC}$ and ${ }^{18} \mathrm{~F}$-FACPC have shown that these ${ }^{18} \mathrm{~F}$-labeled AA tracers can accurately detect tumor and regional lymph node metastases of prostate cancer with better specificity and sensitivity. ${ }^{18} \mathrm{~F}$-fluciclovine used in breast cancer PET/ $\mathrm{CT}$ imaging have been reported. ${ }^{18} \mathrm{~F}$-fluciclovine PET/ $\mathrm{CT}$ visualizes malignant tumors including invasive lobular breast cancer (ILC) and invasive ductal breast cancer (IDC). In primary and metastatic breast cancers, ${ }^{18}$ F-fluciclovine uptake was significantly higher than benign breast lesions and normal breast tissue. In the future, we have some innovative and interesting ${ }^{18} \mathrm{~F}$-labeled amino acid anologues available, such as ${ }^{18}$ F-BAAs (boramino acids), which demonstrated distinctly high AA transporter-mediated tumor uptake and rapid clearance from normal organs and tissues [7]. However, the role of ${ }^{18} \mathrm{~F}$-labeled amino acids PET will be limited to diagnostic imaging only. In the era of theranostic medicine, the peptide-receptor imaging and further peptide-receptor radionuclide therapy (PRRT) are emerging for somatostatin-related neuroendocrine tumors and prostate cancers, for example, DOTA-TOC and DOTATATE PET/CT [89-93].

\section{CONFLICTS OF INTEREST}

No potential conflicts of interest were disclosed.

\section{FUNDING}

This study was funded by the Natural Science Foundation of China (NSFC81172133, NSFC81372413), the Special Fund for Scientific Research in the Public Interest (201402011), the Projects of Medical and Health Technology Development Program in Shandong Province (2014WS0058) and the Outstanding Youth Natural Science Foundation of Shandong Province (JQ201423).

\section{REFERENCES}

1. McConathy J, Goodman MM. Non-natural amino acids for tumor imaging using positron emission tomography and single photon emission computed tomography. Cancer Metastasis Rev. 2008; 27:555-73.

2. McConathy J, Yu W, Jarkas N, Seo W, Schuster DM, Goodman MM. Radiohalogenated nonnatural amino acids as PET and SPECT tumor imaging agents. Med Res Rev. 2012; 32:868-905.

3. Ulaner GA, Goldman D, Corben A, Lyashchenko SK, Gönen M, Lewis JS, Dickler M. A prospective clinical trial of 18F-Fluciclovine PET/CT neoadjuvant therapy response in invasive ductal and invasive lobular breast cancers. J Nucl Med. 2016; 58:1037-1042.

4. Stenhagen IS, Kirjavainen AK, Forsback SJ, Jørgensen CG, Robins EG, Luthra SK, Solin O, Gouverneur V. [18F] fluorination of an arylboronic ester using [18F]selectfluor bis(triflate): application to 6-[18F]fluoro-L-DOPA. Chem Commun (Camb). 2013; 49:1386-8.

5. Wagner FM, Ermert J, Coenen HH. Three-step, "one-pot" radiosynthesis of 6-fluoro-3,4-dihydroxy-L-phenylalanine by isotopic exchange. J Nucl Med. 2009; 50:1724-9.

6. Liu Z, Chen H, Chen K, Shao Y, Kiesewetter DO, Niu G, Chen X. Boramino acid as a marker for amino acid transporters. Sci Adv. 2015; 1:e1500694.

7. Huang C, McConathy J. Radiolabeled amino acids for oncologic imaging. J Nucl Med. 2013; 54:1007-10.

8. Witte D, Ali N, Carlson N, Younes M. Overexpression of the neutral amino acid transporter ASCT2 in human colorectal adenocarcinoma. Anticancer Res. 2002; 22:2555-7.

9. Shennan DB, Thomson J. Inhibition of system L (LAT1/ CD98hc) reduces the growth of cultured human breast cancer cells. Oncol Rep. 2008; 20:885-9.

10. Fuchs BC, Bode BP. Amino acid transporters ASCT2 and LAT1 in cancer: partners in crime. Semin Cancer Biol. 2005; 15:254-66.

11. Ganapathy V, Thangaraju M, Prasad PD. Nutrient transporters in cancer: relevance to Warburg hypothesis and beyond. Pharmacol Ther. 2009; 121:29-40.

12. Nakanishi T, Tamai I. Solute carrier transporters as targets for drug delivery and pharmacological intervention for chemotherapy. J Pharm Sci. 2011; 100:3731-50.

13. Wagner CA, Lang F, Bröer S. Function and structure of heterodimeric amino acid transporters. Am J Physiol Cell Physiol. 2001; 281:C1077-93. 
14. Langen KJ, Bröer S. Molecular transport mechanisms of radiolabeled amino acids for PET and SPECT. J Nucl Med. 2004; 45:1435-6.

15. Mackenzie B, Erickson JD. Sodium-coupled neutral amino acid (System N/A) transporters of the SLC38 gene family. Pflugers Arch. 2004; 447:784-95.

16. Verrey F. System L: heteromeric exchangers of large, neutral amino acids involved in directional transport. Pflugers Arch. 2003; 445:529-33.

17. Ishiwata K, Kubota K, Murakami M, Kubota R, Senda M. A comparative study on protein incorporation of L-[methyl-3H] methionine, L-[1-14C]leucine and L-2-[18F]fluorotyrosine in tumor bearing mice. Nucl Med Biol. 1993; 20:895-9.

18. Jager PL, Vaalburg W, Pruim J, de Vries EG, Langen KJ, Piers DA. Radiolabeled amino acids: basic aspects and clinical applications in oncology. J Nucl Med. 2001; 42:432-45.

19. Hyde R, Taylor PM, Hundal HS. Amino acid transporters: roles in amino acid sensing and signalling in animal cells. Biochem J. 2003; 373(Pt 1): 1-18.

20. Franchi-Gazzola R, Gaccioli F, Bevilacqua E, Visigalli R, Dall'Asta V, Sala R, Varoqui H, Erickson JD, Gazzola GC, Bussolati O. The synthesis of SNAT2 transporters is required for the hypertonic stimulation of system A transport activity. Biochim Biophys Acta. 2004; 1667:157-66.

21. Uchino H, Kanai Y, Kim DK, Wempe MF, Chairoungdua A, Morimoto E, Anders MW, Endou H. Transport of amino acid-related compounds mediated by L-type amino acid transporter 1 (LAT1): insights into the mechanisms of substrate recognition. Mol Pharmacol. 2002; 61:729-37.

22. Hediger MA, Romero MF, Peng JB, Rolfs A, Takanaga H, Bruford EA. The ABCs of solute carriers: physiological, pathological and therapeutic implications of human membrane transport proteins. Pflugers Arch. 2004; 447:465-8.

23. Closs EI, Boissel JP, Habermeier A, Rotmann A. Structure and function of cationic amino acid transporters (CATs). J Membr Biol. 2006; 213:67-77.

24. Verrey F, Closs EI, Wagner CA, Palacin M, Endou H, Kanai Y. CATs and HATs: the SLC7 family of amino acid transporters. Pflugers Arch. 2004; 447:532-42.

25. Kanai Y, Hediger MA. The glutamate and neutral amino acid transporter family: physiological and pharmacological implications. Eur J Pharmacol. 2003; 479(1-3): 237-47.

26. Kanai Y, Hediger MA. The glutamate/neutral amino acid transporter family SLC1: molecular, physiological and pharmacological aspects. Pflugers Arch. 2004; 447:469-79.

27. Laverman P, Boerman OC, Corstens FH, Oyen WJ. Fluorinated amino acids for tumour imaging with positron emission tomography. Eur J Nucl Med Mol Imaging. 2002; 29:681-90.

28. Schirrmeister H, Kühn T, Guhlmann A, Santjohanser C, Hörster T, Nüssle K, Koretz K, Glatting G, Rieber A, Kreienberg R, Buck AC, Reske SN. Fluorine-18 2-deoxy-2-
fluoro-D-glucose PET in the preoperative staging of breast cancer: comparison with the standard staging procedures. Eur J Nucl Med. 2001; 28:351-8.

29. van der Hiel B, Pauwels EK, Stokkel MP. Positron emission tomography with 2-[18F]-fluoro-2-deoxy-D-glucose in oncology. Part IIIa: Therapy response monitoring in breast cancer, lymphoma and gliomas. J Cancer Res Clin Oncol. 2001; 127:269-77.

30. Czernin J, Allen-Auerbach M, Schelbert HR. Improvements in cancer staging with PET/CT: literature-based evidence as of September 2006. J Nucl Med. 2007; 48:78S-88S.

31. Juweid ME, Cheson BD. Positron-emission tomography and assessment of cancer therapy. N Engl J Med. 2006; 354:496-507.

32. Galldiks N, Langen KJ. Amino Acid PET - An Imaging Option to Identify Treatment Response, Posttherapeutic Effects, and Tumor Recurrence. Front Neurol. 2016; 7:120.

33. Herrmann K, Czernin J, Cloughesy T, Lai A, Pomykala KL, Benz MR, Buck AK, Phelps ME, Chen W. Comparison of visual and semiquantitative analysis of 18F-FDOPA-PET/ $\mathrm{CT}$ for recurrence detection in glioblastoma patients. Neuro Oncol. 2014; 16:603-9.

34. Tscherpel C, Dunkl V, Ceccon G, Stoffels G, Judov N, Rapp M, Meyer PT, Kops ER, Ermert J, Fink GR, Shah NJ, Langen KJ, Galldiks N. The use of O-(2-18F-fluoroethyl)L-tyrosine PET in the diagnosis of gliomas located in the brainstem and spinal cord. Neuro Oncol. 2016; 19:710-718.

35. Dunet V, Rossier C, Buck A, Stupp R, Prior JO. Performance of 18F-fluoro-ethyl-tyrosine (18F-FET) PET for the differential diagnosis of primary brain tumor: a systematic review and Metaanalysis. J Nucl Med. 2012; 53:207-14.

36. Galldiks N, Stoffels G, Filss CP, Piroth MD, Sabel M, Ruge MI, Herzog H, Shah NJ, Fink GR, Coenen HH, Langen KJ. Role of O-(2-(18)F-fluoroethyl)-L-tyrosine PET for differentiation of local recurrent brain metastasis from radiation necrosis. J Nucl Med. 2012; 53:1367-74.

37. Verger A, Metellus P, Sala Q, Colin C, Bialecki E, Taieb D, Chinot O, Figarella-Branger D, Guedj E. IDH mutation is paradoxically associated with higher (18)F-FDOPA PET uptake in diffuse grade II and grade III gliomas. Eur J Nucl Med Mol Imaging. 2017; 44:1306-1311.

38. Morana G, Puntoni M, Garrè ML, Massollo M, Lopci E, Naseri M, Severino M, Tortora D, Rossi A, Piccardo A. Ability of F-DOPA PET/CT and fused (18)F-DOPA PET/ MRI to assess striatal involvement in paediatric glioma. Eur J Nucl Med Mol Imaging. 2016; 43:1664-72.

39. Miyatake S, Tamura Y, Kawabata S, Iida K, Kuroiwa T, Ono K. Boron neutron capture therapy for malignant tumors related to meningiomas. Neurosurgery. 2007; 61:82-90; discussion 90-1.

40. Aihara T, Hiratsuka J, Morita N, Uno M, Sakurai Y, Maruhashi A, Ono K, Harada T. First clinical case of boron neutron capture therapy for head and neck malignancies using 18F-BPA PET. Head Neck. 2006; 28:850-5. 
41. Miyatake S, Kawabata S, Kajimoto Y, Aoki A, Yokoyama K, Yamada M, Kuroiwa T, Tsuji M, Imahori Y, Kirihata M, Sakurai Y, Masunaga S, Nagata K, et al. Modified boron neutron capture therapy for malignant gliomas performed using epithermal neutron and two boron compounds with different accumulation mechanisms: an efficacy study based on findings on neuroimages. J Neurosurg. 2005; 103:1000-9.

42. Mittra ES, Koglin N, Mosci C, Kumar M, Hoehne A, Keu KV, Iagaru AH, Mueller A, Berndt M, Bullich S, Friebe M, Schmitt-Willich H, Gekeler V, et al. Pilot Preclinical and Clinical Evaluation of (4S)-4-(3-[18F]Fluoropropyl)-LGlutamate (18F-FSPG) for PET/CT Imaging of Intracranial Malignancies. PLoS One. 2016; 11:e0148628.

43. Venneti S, Dunphy MP, Zhang H, Pitter KL, Zanzonico P, Campos C, Carlin SD, La Rocca G, Lyashchenko S, Ploessl K, Rohle D, Omuro AM, Cross JR, et al. Glutaminebased PET imaging facilitates enhanced metabolic evaluation of gliomas in vivo. Sci Transl Med. 2015; 7:274ra17.

44. Zhu L, Ploessl K, Zhou R, Mankoff D, Kung HF. Metabolic Imaging of Glutamine in Cancer. J Nucl Med. 2017; 58:533-537.

45. Lieberman BP, Ploessl K, Wang L, Qu W, Zha Z, Wise DR, Chodosh LA, Belka G, Thompson CB, Kung HF. PET imaging of glutaminolysis in tumors by $18 \mathrm{~F}-(2 \mathrm{~S}, 4 \mathrm{R}) 4-$ fluoroglutamine. J Nucl Med. 2011; 52:1947-55.

46. Hassanein M, Hight MR, Buck JR, Tantawy MN, Nickels ML, Hoeksema MD, Harris BK, Boyd K, Massion PP, Manning HC. Preclinical Evaluation of 4-[18F] Fluoroglutamine PET to Assess ASCT2 Expression in Lung Cancer. Mol Imaging Biol. 2016; 18:18-23.

47. Kulke MH, Siu LL, Tepper JE, Fisher G, Jaffe D, Haller DG, Ellis LM, Benedetti JK, Bergsland EK, Hobday TJ, Van Cutsem E, Pingpank J, Oberg K, et al. Future directions in the treatment of neuroendocrine tumors: consensus report of the National Cancer Institute Neuroendocrine Tumor clinical trials planning meeting. J Clin Oncol. 2011; 29:934-43.

48. Sundin A, Garske U, Orlefors H. Nuclear imaging of neuroendocrine tumours. Best Pract Res Clin Endocrinol Metab. 2007; 21:69-85.

49. van Eeden S, Offerhaus GJ. Historical, current and future perspectives on gastrointestinal and pancreatic endocrine tumors. Virchows Arch. 2006; 448:1-6.

50. Heimburger C, Veillon F, Taïeb D, Goichot B, Riehm S, Petit-Thomas J, Averous G, Cavalcanti M, Hubelé F, Chabrier G, Namer IJ, Charpiot A, Imperiale A. Headto-head comparison between (18)F-FDOPA PET/CT and $\mathrm{MR} / \mathrm{CT}$ angiography in clinically recurrent head and neck paragangliomas. Eur J Nucl Med Mol Imaging. 2017; 44:979-987.

51. Feral CC, Tissot FS, Tosello L, Fakhry N, Sebag F, Pacak K, Taïeb D. (18)F-fluorodihydroxyphenylalanine PET/CT in pheochromocytoma and paraganglioma: relation to genotype and amino acid transport system L. Eur J Nucl Med Mol Imaging. 2017; 44:812-821.
52. Knie B, Plotkin M, Zschieschang P, Prasad V, Moskopp D. A family with pheochromocytoma-paraganglioma inherited tumour syndrome. Serial 18F-DOPA PET/CT investigations. Nuklearmedizin. 2016; 55:34-40.

53. Deroose CM, Hindié E, Kebebew E, Goichot B, Pacak K, Taïeb D, Imperiale A. Molecular Imaging of Gastroenteropancreatic Neuroendocrine Tumors: Current Status and Future Directions. J Nucl Med. 2016; 57:1949-1956.

54. Piccardo A, Lopci E, Conte M, Garaventa A, Foppiani L, Altrinetti V, Nanni C, Bianchi P, Cistaro A, Sorrentino S, Cabria M, Pession A, Puntoni M, et al. Comparison of 18F-dopa PET/CT and 123I-MIBG scintigraphy in stage 3 and 4 neuroblastoma: a pilot study. Eur J Nucl Med Mol Imaging. 2012; 39:57-71.

55. Jager PL, Chirakal R, Marriott CJ, Brouwers AH, Koopmans KP, Gulenchyn KY. 6-L-18F-fluorodihydroxyphenylalanine PET in neuroendocrine tumors: basic aspects and emerging clinical applications. J Nucl Med. 2008; 49:573-86.

56. Helali M, Addeo P, Heimburger C, Detour J, Goichot B, Bachellier P, Namer IJ, Taïeb D, Imperiale A. Carbidopaassisted (18)F-fluorodihydroxyphenylalanine PET/ CT for the localization and staging of non-functioning neuroendocrine pancreatic tumors. Ann Nucl Med. 2016; 30:659-668.

57. Koopmans KP, de Vries EG, Kema IP, Elsinga PH, Neels OC, Sluiter WJ, van der Horst-Schrivers AN, Jager PL. Staging of carcinoid tumours with 18F-DOPA PET: a prospective, diagnostic accuracy study. Lancet Oncol. 2006; 7:728-34.

58. Moertel CG. Karnofsky memorial lecture. An odyssey in the land of small tumors. J Clin Oncol. 1987; 5:1502-22.

59. Modlin IM, Latich I, Zikusoka M, Kidd M, Eick G, Chan AK. Gastrointestinal carcinoids: the evolution of diagnostic strategies. J Clin Gastroenterol. 2006; 40:572-82.

60. Oberg K. Neuroendocrine tumors of the gastrointestinal tract: recent advances in molecular genetics, diagnosis, and treatment. Curr Opin Oncol. 2005; 17:386-91.

61. Rockall AG, Reznek RH. Imaging of neuroendocrine tumours (CT/MR/US). Best Pract Res Clin Endocrinol Metab. 2007; 21:43-68.

62. Hoegerle S, Altehoefer C, Ghanem N, Brink I, Moser E, Nitzsche E. 18F-DOPA positron emission tomography for tumour detection in patients with medullary thyroid carcinoma and elevated calcitonin levels. Eur J Nucl Med. 2001; 28:64-71.

63. Beuthien-Baumann B, Strumpf A, Zessin J, Bredow J, Kotzerke J. Diagnostic impact of PET with 18F-FDG, 18F-DOPA and 3-O-methyl-6-[18F]fluoro-DOPA in recurrent or metastatic medullary thyroid carcinoma. Eur J Nucl Med Mol Imaging. 2007; 34:1604-9.

64. Rösch T, Lightdale CJ, Botet JF, Boyce GA, Sivak MV Jr, Yasuda K, Heyder N, Palazzo L, Dancygier H, Schusdziarra V. Localization of pancreatic endocrine tumors by endoscopic ultrasonography. N Engl J Med. 1992; 326:1721-6. 
65. Anderson MA, Carpenter S, Thompson NW, Nostrant TT, Elta GH, Scheiman JM. Endoscopic ultrasound is highly accurate and directs management in patients with neuroendocrine tumors of the pancreas. Am J Gastroenterol. 2000; 95:2271-7.

66. Hellman P, Hennings J, Akerström G, Skogseid B. Endoscopic ultrasonography for evaluation of pancreatic tumours in multiple endocrine neoplasia type 1 . Br J Surg. 2005; 92:1508-12.

67. Ferlay J, Shin HR, Bray F, Forman D, Mathers C, Parkin DM. Estimates of worldwide burden of cancer in 2008: GLOBOCAN 2008. Int J Cancer. 2010; 127:2893-917.

68. Shoup TM, Olson J, Hoffman JM, Votaw J, Eshima D, Eshima L, Camp VM, Stabin M, Votaw D, Goodman MM. Synthesis and evaluation of [18F]1-amino-3fluorocyclobutane-1-carboxylic acid to image brain tumors. J Nucl Med. 1999; 40:331-8.

69. Suzuki H, Inoue Y, Fujimoto H, Yonese J, Tanabe K, Fukasawa S, Inoue T, Saito S, Ueno M, Otaka A. Diagnostic performance and safety of NMK36 (trans-1-amino-3-[18F] fluorocyclobutanecarboxylic acid)-PET/CT in primary prostate cancer: multicenter Phase IIb clinical trial. Jpn J Clin Oncol. 2016; 46:152-62.

70. Schuster DM, Votaw JR, Nieh PT, Yu W, Nye JA, Master V, Bowman FD, Issa MM, Goodman MM. Initial experience with the radiotracer anti-1-amino-3-18F-fluorocyclobutane1-carboxylic acid with PET/CT in prostate carcinoma. J Nucl Med. 2007; 48:56-63.

71. Nanni C, Schiavina R, Boschi S, Ambrosini V, Pettinato C, Brunocilla E, Martorana G, Fanti S. Comparison of $18 \mathrm{~F}-\mathrm{FACBC}$ and $11 \mathrm{C}$-choline PET/CT in patients with radically treated prostate cancer and biochemical relapse: preliminary results. Eur J Nucl Med Mol Imaging. 2013; 40:S11-7.

72. Schuster DM, Nieh PT, Jani AB, Amzat R, Bowman FD, Halkar RK, Master VA, Nye JA, Odewole OA, Osunkoya AO, Savir-Baruch B, Alaei-Taleghani P, Goodman MM. Anti-3[(18)F]FACBC positron emission tomography-computerized tomography and (111)In-capromab pendetide single photon emission computerized tomography-computerized tomography for recurrent prostate carcinoma: results of a prospective clinical trial. J Urol. 2014; 191:1446-53.

73. Nanni C, Schiavina R, Brunocilla E, Boschi S, Borghesi M, Zanoni L, Pettinato C, Martorana G, Fanti S. 18F-Fluciclovine PET/CT for the Detection of Prostate Cancer Relapse: A Comparison to 11C-Choline PET/CT. Clin Nucl Med. 2015; 40:e386-91.

74. Schuster DM, Nanni C, Fanti S. Evaluation of Prostate Cancer with Radiolabeled Amino Acid Analogs. J Nucl Med. 2016; 57:61S-66S.

75. Derlon JM, Bourdet C, Bustany P, Chatel M, Theron J, Darcel F, Syrota A. [11C]L-methionine uptake in gliomas. Neurosurgery. 1989; 25:720-8.

76. Kameyama M, Shirane R, Itoh J, Sato K, Katakura R, Yoshimoto T, Hatazawa J, Itoh M, Ido T. The accumulation of $11 \mathrm{C}$-methionine in cerebral glioma patients studied with PET. Acta Neurochir (Wien). 1990; 104:8-12.

77. Nanni C, Zanoni L, Pultrone C, Schiavina R, Brunocilla E, Lodi F, Malizia C, Ferrari M, Rigatti P, Fonti C, Martorana G, Fanti S. (18)F-FACBC (anti1-amino-3-(18) F-fluorocyclobutane-1-carboxylic acid) versus (11)C-choline $\mathrm{PET} / \mathrm{CT}$ in prostate cancer relapse: results of a prospective trial. Eur J Nucl Med Mol Imaging. 2016; 43:1601-10.

78. Brunocilla E, Schiavina R, Nanni C, Borghesi M, Cevenini M, Molinaroli E, Vagnoni V, Castellucci P, Ceci F, Fanti S, Gaudiano C, Golfieri R, Martorana G. First case of 18F-FACBC PET/CT-guided salvage radiotherapy for local relapse after radical prostatectomy with negative 11C-Choline PET/CT and multiparametric MRI: New imaging techniques may improve patient selection. Arch Ital Urol Androl. 2014; 86:239-40.

79. Schiavina R, Concetti S, Brunocilla E, Nanni C, Borghesi M, Gentile G, Cevenini M, Bianchi L, Molinaroli E, Fanti S, Martorana G. First case of 18F-FACBC PET/CT-guided salvage retroperitoneal lymph node dissection for disease relapse after radical prostatectomy for prostate cancer and negative 11C-choline PET/CT: new imaging techniques may expand pioneering approaches. Urol Int. 2014; 92:242-5.

80. Nanni C, Schiavina R, Brunocilla E, Borghesi M, Ambrosini V, Zanoni L, Gentile G, Vagnoni V, Romagnoli D, Martorana G, Fanti S. 18F-FACBC compared with $11 \mathrm{C}$-choline $\mathrm{PET} / \mathrm{CT}$ in patients with biochemical relapse after radical prostatectomy: a prospective study in 28 patients. Clin Genitourin Cancer. 2014; 12:106-10.

81. Elschot M, Selnæs KM, Sandsmark E, Krüger-Stokke B, Størkersen Ø, Tessem MB, Moestue SA, Bertilsson H, Bathen TF. A PET/MRI study towards finding the optimal [(18)F]Fluciclovine PET protocol for detection and characterisation of primary prostate cancer. Eur J Nucl Med Mol Imaging. 2017; 44:695-703.

82. Schreibmann E, Schuster DM, Rossi PJ, Shelton J, Cooper S, Jani AB. Image Guided Planning for Prostate Carcinomas With Incorporation of Anti-3-[18F]FACBC (Fluciclovine) Positron Emission Tomography: Workflow and Initial Findings From a Randomized Trial. Int J Radiat Oncol Biol Phys. 2016; 96:206-13.

83. McConathy J. 18F-Fluciclovine (FACBC) and Its Potential Use for Breast Cancer Imaging. J Nucl Med. 2016; 57:1329-30.

84. Tade FI, Cohen MA, Styblo TM, Odewole OA, Holbrook AI, Newell MS, Savir-Baruch B, Li X, Goodman MM, Nye JA, Schuster DM. Anti-3-18F-FACBC (18F-Fluciclovine) PET/CT of Breast Cancer: An Exploratory Study. J Nucl Med. 2016; 57:1357-63.

85. Ulaner GA, Goldman DA, Gönen M, Pham H, Castillo R, Lyashchenko SK, Lewis JS, Dang C. Initial Results of a Prospective Clinical Trial of 18F-Fluciclovine PET/CT in Newly Diagnosed Invasive Ductal and Invasive Lobular Breast Cancers. J Nucl Med. 2016; 57:1350-6. 
86. Webster JM, Morton CA, Johnson BF, Yang H, Rishel MJ, Lee BD, Miao Q, Pabba C, Yapp DT, Schaffer P. Functional imaging of oxidative stress with a novel PET imaging agent, 18F-5-fluoro-L-aminosuberic acid. J Nucl Med. 2014; 55:657-64.

87. Yang H, Jenni S, Colovic M, Merkens H, Poleschuk C, Rodrigo I, Miao Q, Johnson BF, Rishel MJ, Sossi V, Webster JM, Bénard F, Schaffer P. (18)F-5-Fluoroaminosuberic Acid as a Potential Tracer to Gauge Oxidative Stress in Breast Cancer Models. J Nucl Med. 2017; 58:367-373.

88. Zhou R, Pantel AR, Li S, Lieberman BP, Ploessl K, Choi H, Blankemeyer E, Lee H, Kung HF, Mach RH, Mankoff DA. [(18)F](2S,4R)4-Fluoroglutamine PET Detects Glutamine Pool Size Changes in Triple-Negative Breast Cancer in Response to Glutaminase Inhibition. Cancer Res. 2017; 77:1476-1484.

89. Holmboe S, Hansen PL, Thisgaard H, Block I, Müller C, Langkjær N, Høilund-Carlsen PF, Olsen BB, Mollenhauer J. Evaluation of somatostatin and nucleolin receptors for therapeutic delivery in non-small cell lung cancer stem cells applying the somatostatin-analog DOTATATE and the nucleolin-targeting aptamer AS1411. PLoS One. 2017; 12:e0178286.
90. Naik C, Basu S. Peptide Receptor Radionuclide Therapy with (177)Lu-DOTATATE for Metastatic Neuroendocrine Tumor Occurring in Association with Multiple Endocrine Neoplasia Type 1 and Cushing's Syndrome. World J Nucl Med. 2017; 16:126-132.

91. Hänscheid H, Lapa C, Buck AK, Lassmann M, Werner RA. Dose Mapping after Endoradiotherapy with (177)LuDOTATATE/-TOC by One Single Measurement after Four Days. J Nucl Med. 2017. http://doi.org/jnumed.117.193706 [Epub ahead of print].

92. Gauthé M, Sarfati J, Bourcigaux N, Christin-Maitre S, Talbot JN, Montravers F. Pituitary Adenoma Recurrence Suspected on Central Hyperthyroidism Despite Empty Sella and Confirmed by $68 \mathrm{Ga}-\mathrm{DOTA}-\mathrm{TOC}$ PET/CT. Clin Nucl Med. 2017; 42:454-455.

93. Papamichail DG, Exadaktylou PE, Chatzipavlidou VD. [Neuroendocrine tumors: Peptide receptors radionuclide therapy (PRRT)]. Hell J Nucl Med. 2016; 19:75-82. 